\title{
Development of the Hostility in Pandemic Scale (HPS): A Validity and Reliability Study
}

\author{
Emine Burcu Tunc ${ }^{\circledR 1}{ }^{*}$, Simel Parlak ${ }^{(12}$, Muge Uluman ${ }^{(1}$, Derya Eryigit ${ }^{\circledR 1}$
}

${ }^{1}$ Department of Educational Sciences, Faculty of Education, Marmara University, Istanbul, Turkey

${ }^{2}$ Department of Educational Sciences, Faculty of Education, Istanbul Okan University, Istanbul, Turkey

\author{
ARTICLE HISTORY \\ Received: Dec. 08, 2020 \\ Revised: Jan. 13, 2021 \\ Accepted: May 16, 2021 \\ Keywords: \\ Hostility in pandemic, \\ Pandemic, \\ Hostility, \\ Scale development, \\ Validity.
}

\begin{abstract}
The aim of this research is to develop Hostility in Pandemic Scale (HPS) for Turkey Population to determine the hostility levels of individuals, which is a factor affecting the mental well-being of the society during the pandemic. The study group consists of 855 individuals between the ages of 18-65 from different genders, and have experienced the pandemic process. For the construct validity of the scale results, exploratory factor analysis was conducted and a one-dimensional structure consisting of 22 items was revealed. It was determined that the variance explained by the scale showing a one-dimensional structure was $41.5 \%$. As a result of the confirmatory factor analysis performed through a separate study group, it was revealed that all items have significant $t$ values, and the model established according to model fit indexes has meaningful and acceptable fit values. BussPerry Aggression Scale was applied with HPS for the criterion validity. As a result of the criterion validity analysis, a significant relationship was found between the scale scores. The Cronbach Alpha was calculated to analyses internal consistency of the scale and a reliability level of 0.93 was obtained. The test-retest reliability results were found as 0.89 . In addition, item statistics revealed that all of the scale items can discriminate well among the respondents. Results of the analysis revealed that, the Hostility Scale in Pandemic Process provides valid and reliable results.
\end{abstract}

\section{INTRODUCTION}

Pandemic triggers changes in the psychological and sociological structure of the society. Therefore, understanding the epidemiology of the pandemic and defining the changes occurring in the societies undergoing the pandemic process is necessary to guide not only the current pandemic, but also the repetitive waves of the same virus and public health responses in future pandemics (Trauer et al., 2011). During the pandemic, individuals might face post-traumatic stress disorder (Lee et al., 2018), stress, anxiety, depressive symptoms, rejection, fear and anger (Jones et al., 2017). Negative effects on psychological well-being in the society may lead to the development of hostile feelings and actions regarding the emergence and spread of the virus.

Hostility is a complex set of tendencies that includes negative beliefs, angry emotions, and aggressive interactions (Spilberger et al., 1983), but can also be seen as a transient state (Rosenman, 1991) or a stable personality trait (Miller et al., 1996). Although closely related,

\footnotetext{
*CONTACT: Emine Burcu TUNÇ $\bigotimes$ burcu.tunc@marmara.edu.tr
} Department of Educational Sciences, Faculty of Education, Marmara University, Istanbul, Turkey 
hostility appears to be more precisely differentiated from both anger and aggression, as it combines attitudinal and cognitive characteristics (Gambone, 1999). Considering the literature on hostility, it can be stated that the focus is primarily on the link between personality and negative health outcomes (Becker \& Lesiak, 1977; Faay et al., 2020; Keith et al., 2017; Ranchor et al., 1997). It is also recognized that social-environmental conditions and genetics are important dynamics in the formation and maintenance of hostility (Contrada, 1994). Hostility, which is a negative attitude, often causes people to experience anger. The individual, who has a hostile attitude, experiences a negative and pessimistic view of the world, distrust towards other people and a desire to harm. These individuals generally worry about problems and cannot cope with uncertainty (Eckhardt, Bradley \& Deffenbacher, 2004). In addition, these individuals who have difficulty reading social cues display aggressive behavior in their social interactions (Suls \& Bunde 2005). Individuals who have a hostile attitude experience stress due to having a pessimistic perspective, anger and aggression. This stress negatively affects the mental and social lives of individuals, who have a hostile attitude, and causes health problems (Maan Diong et al., 2005).

Hostility is related with many outcomes in the social health and it is important that these relationships could be analyzed statistically. Thus, there are several assessment tools in the literature to be used in the studies to assess hostility with different variables. Buss and Durke (1957) developed an inventory in order to assess different kinds of hostility, such as: Assault, Indirect Hostility, Irritability, Negativism, Resentment, Suspicion, Verbal Hostility, and Guilt. In their scale, Cook and Medley (1957) associated hostility with enhanced risk for physical disorders, psychological dysfunction, and problems in interpersonal relationships. Xenophobia Scale by Veer et al., (2013) is developed to assess the xenophobia; hostility towards people from a different country, ethnic or cultural group. This scale is adapted to Turkish by Özmete, Y1ldırım and Duru (2012). Bussy and Perry (1992) developed Hostility scale which is the most common used hostility scales and is adapted to Turkish by Madran. (2012). Although there are several hostility scales developed in the literature, there is not a scale developed about hostility in pandemic, which still changes the society.

In the study carried out by Becerra-García et al., (2020) with 151 participants between the ages of 18-76, it was found that individuals between the ages of 18-35 have higher rates of hostility. Similarly, in the study conducted by Pérez-Fuentes et al., (2020) with 1004 participants, it was found that the perceived threat from Covid-19 has a direct positive effect on sadness-depression, anxiety and anger-hostility moods, and that anxiety and anger-hostility directly affect the perception of threat from the virus.

Considering that Covid-19 creates many psychological and sociological problems in the individual such as panic, anxiety and hostility; it is clear that revealing the psychological aspects of the fight against Covid-19 will contribute to the social mental health (Jakovljevic et al., 2020). Hostility can manifest in emerging and invisible ways in behavior, and the presence of hostility is a variable that affects how the society will go through the pandemic process. For the aforementioned reasons, in this study, it was aimed to develop the Hostility Scale in the Pandemic Process to determine the hostility levels exhibited by individuals during the pandemic.

\section{METHOD}

In this study, it was aimed to develop a measurement tool for determining the hostility levels of individuals during the pandemic. This research is a scale development study. The information about the study group and the processes followed in the development of the Hostility in the Pandemic Scale (HPS) are given below. 


\subsection{Study Group}

The study group of this research consists of 855 individuals between the ages of 18-65. In this context, the values in Table 1 were reached by removing outliers at each stage, and analyzes were carried out on a total of 855 individuals. The necessary ethical approval is obtained before the study and the informed consent of the participants were obtained before the application of the scale.

Table 1. Working groups included in the study.

\begin{tabular}{|c|c|c|c|}
\hline Study groups & $\begin{array}{l}\text { Applied scale } \\
\text { / scales }\end{array}$ & $\begin{array}{l}\text { Performed } \\
\text { statistical transactions }\end{array}$ & $\begin{array}{l}\text { Number of } \\
\text { individuals }\end{array}$ \\
\hline First Study Group & HPS & $\begin{array}{l}\text { Application of EFA for construct validity } \\
\text { and testing internal consistency }\end{array}$ & 370 individuals \\
\hline Second Study Group & HPS & Application of CFA for construct validity & 353 individuals \\
\hline Third Study Group & $\begin{array}{l}\text { Aggression } \\
\text { Scale with } \\
\text { HPS }\end{array}$ & $\begin{array}{l}\text { Calculating the relationship between the } \\
\text { scores of two scales for criterion validity }\end{array}$ & 75 individuals \\
\hline Fourth Study Group & HPS & $\begin{array}{l}\text { Calculation of the relationship between } \\
\text { the first and second applications for test- } \\
\text { retest reliability }\end{array}$ & 57 individuals \\
\hline
\end{tabular}

The first study group consisted of 370 individuals after the outliers were removed. Individuals between the ages of $18-65$ were reached. $29 \%(n=108)$ of the group are men and $71 \%(n=262)$ are women. Among the main study groups, 353 individuals were reached for the second study group. $20 \%$ of the group are men $(n=71)$ and $80 \%(n=282)$ are women. Another 75 individuals were part of the study group for criterion validity and 57 individuals for test-retest reliability.

\subsection{Development Process of the Scale}

Firstly, the related literature on the pandemic process and the concept of hostility was reviewed. Based on the literature review, the general framework of the concept of hostility, considering the points that the pandemic and hostility are compatible with, the expressions that can be included in the scale have been examined and discussed. As a result, 39 items in total were written by the researchers. The scale items were evaluated by a total of six experts, two assessment and evaluation experts, two guidance and psychological counseling experts, and two Turkish language experts. In accordance with the opinions of the experts, items that are difficult to understand, that are irrelevant with the subject, and that contain more than one jurisdiction have been revised or removed from the scale in line with the recommendations. In this direction, the final trial form consisting of 35 items was obtained. The scale is a five-point Likert-type, rated as 1. Strongly disagree, 2. Disagree, 3. Undecided, 4. Agree, and 5. Strongly agree.

In the first step, the Explanatory Factor Analysis (EFA) was applied to reveal the construct validity of the scale. At this stage, factor loadings were mainly taken into consideration while deciding on the items that should be included in the scale. According to Tabachnick \& Fidell (2007), and Kline (2011), factor loadings should be at least 0.32 . Therefore, 0.32 was accepted as the criterion value for the factor loadings in the current study. The Cronbach Alpha reliability coefficient was used to test the internal consistency of the results obtained from the scale whose construct validity was proven. Crocker \& Algina (1986) and Tan (2009) stated that the reliability coefficients in the range of $0.70-0.80$ are acceptable. In this study, this criterion was taken into account for internal consistency.

In the second stage, the Confirmatory Factor Analysis (CFA) was conducted to test the accuracy of the structure revealed in the first stage. The CFA is used in examinations to test a model 
developed by the researcher in line with this theory (Tavşanc1l, 2009). Therefore, the onedimensional structure revealed by the EFA was examined based on the CFA. The fact that all $\mathrm{t}$-values in a measurement model are meaningful, indicates that the items in the model are compatible with the model and should be included in the scale (Byrne, 2010). However, as a criterion of whether the measurement model is an acceptable model as a whole, fit index values should also be examined (Şimşek, 2007). In this study, after conducting the EFA, the fit index values provided by the CFA were examined emphasized and the construct validity of the scale was tried to be proven.

In the third stage, Spearman's rho correlation coefficient between HPS and the results obtained from the Buss \& Perry Aggression Scale was examined within the scope of criterion-based validity. Normality assumption could not be achieved therefore spearman correlation was used (for two scale, Kolmogorov-Smirnov test, $p<0.05 ; p=0.00$ ). The Buss \& Perry Aggression Scale was developed by Buss and Perry (1992) and adapted to Turkish culture by Demirtaş Madran (2012). The scale consists consisting of 29 items with a five-point Likert type and four subdimensions: physical aggression, verbal aggression, hostility and anger. As a result of the validity and reliability analysis of the Turkish form, it was revealed that the scale provides reliable and valid results. In the fourth stage, for test and re-test reliability, HPS was administreted on the same group at two weeks interval and significant correlation between two sets of results were found after Pearson correlation analysis. Normality assumption could be achieved therefore Pearson correlation was used (for two sets of results, Kolmogorov-Smirnov test, $p>0.05 ; p=0.22$ ).

\section{FINDINGS}

In this section, findings obtained from the validity and reliability studies of the Hostility in Pandemic Scale (HPS) have been included.

\subsection{Structural Validity}

To analyze the construct validity of the scale, the EFA and CFA were conducted on the data obtained from applying the scale on the study group.

\subsubsection{The exploratory factor analysis (EFA)}

After removing the outliers clearing the extreme values, analyzes were carried out on 370 individuals. The fact that the KMO value is 0.95 and the Barlett Sphericity Test result is significant $\left(\chi^{2}=3806.79, d f=231\right)$ shows that the data is suitable for factor analysis. As a result of the Principal Axis Factoring technique in the EFA, items with a factor loading of less than 0.32 were removed from the initial 35 items. With the remaining 22 items, it was determined that a single-factor structure that explains $41.5 \%$ of the total variance emerged and this singlefactor structure was also suitable for theoretical explanations. As seen in Figure 1 scree plot is the proof of unidimensionality. Cokluk et al., (2012) state that the variance explained $30 \%$ in one-dimensional structures in social sciences is sufficient. Therefore, it has been revealed that the variance explained by the developed scale is also quite sufficient. 
Figure 1. Scree plot.

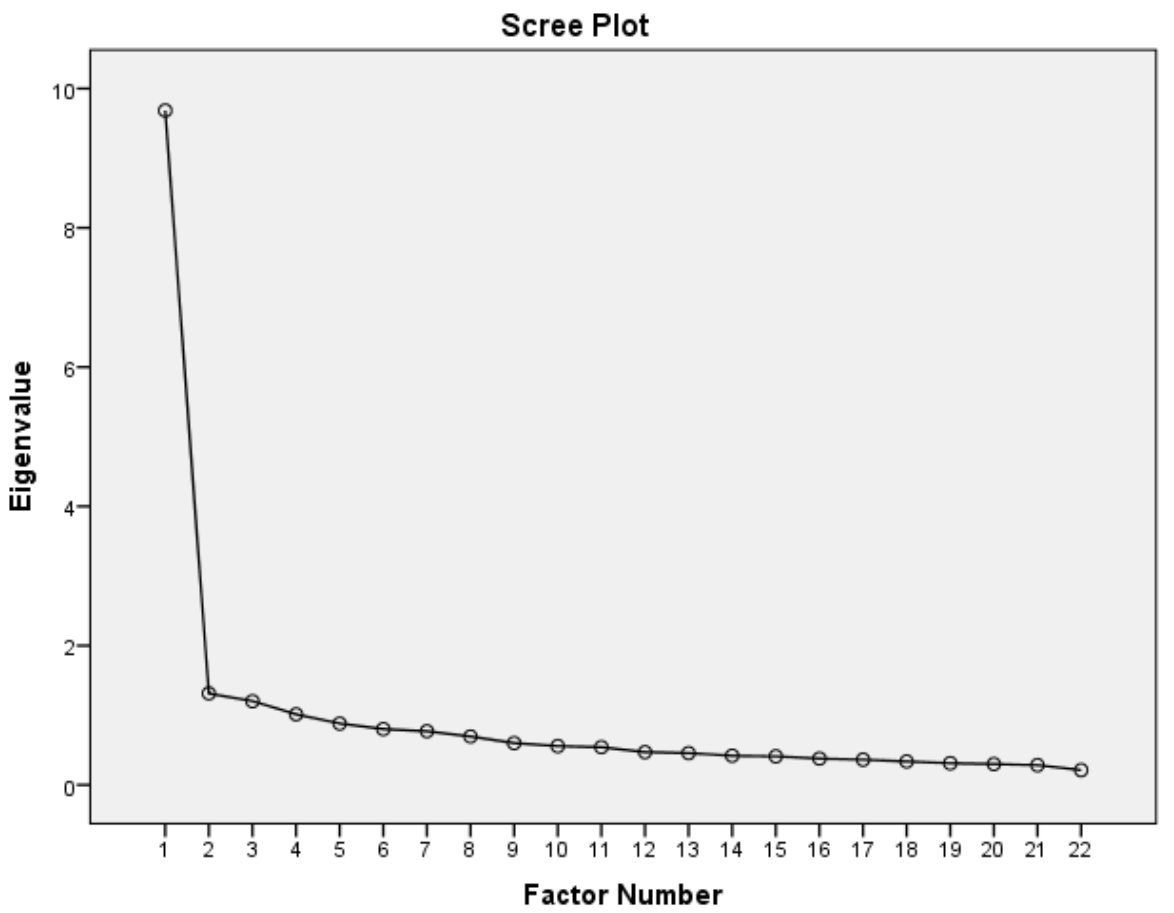

Findings obtained from the EFA are presented in Table 2. According to the results in Table 2, it can be seen that all scale items have factor loadings above the lower limit of 0.32 . It was also revealed that the scale items met criterion value of 0.20 for the explained common variance.

Table 2. Factor structure of the scale and factor loadings.

\begin{tabular}{ccc}
\hline Item no & Factor loading & Common variance \\
\hline I1 & 0.77 & 0.59 \\
I2 & 0.75 & 0.56 \\
I3 & 0.74 & 0.54 \\
I4 & 0.73 & 0.52 \\
I5 & 0.72 & 0.52 \\
I6 & 0.71 & 0.50 \\
I7 & 0.69 & 0.48 \\
I8 & 0.68 & 0.47 \\
I9 & 0.68 & 0.47 \\
I10 & 0.66 & 0.44 \\
I11 & 0.66 & 0.44 \\
I12 & 0.66 & 0.43 \\
I13 & 0.65 & 0.42 \\
I14 & 0.60 & 0.36 \\
I15 & 0.57 & 0.32 \\
I16 & 0.57 & 0.32 \\
I17 & 0.56 & 0.31 \\
I18 & 0.56 & 0.31 \\
I19 & 0.55 & 0.30 \\
I20 & 0.55 & 0.30 \\
I21 & 0.54 & 0.29 \\
I22 & 0.45 & 0.20 \\
\hline
\end{tabular}




\subsubsection{The confirmatory factor analysis (CFA)}

The study group for CFA consists of 353 individuals. It was tested whether the data collected from the second study group confirmed the structure consisting of 22 items and one factor obtained as a result of the EFA. Some of the modifications recommended by the CFA were made to achieve better fit indices. The modifications that were applied include the identification of error covariances among items I1-I4, MI-I13, I17-I18, I20-I21, I13-I11, I15-I3, I8-I2 and I20-I22. Table 3 shows perfect and acceptable fit criteria for fit indices.

Table 3. Perfect and acceptable fit values for fit indices and fit index values obtained from CFA.

\begin{tabular}{|c|c|c|c|c|}
\hline $\begin{array}{l}\text { Reviewed } \\
\text { indices of fit }\end{array}$ & $\begin{array}{l}\text { Perfect fit } \\
\text { criteria }\end{array}$ & $\begin{array}{l}\text { Acceptable fit } \\
\text { criteria }\end{array}$ & $\begin{array}{l}\text { Achieved fit } \\
\text { indexes }\end{array}$ & Conclusion \\
\hline$\chi^{2} / \mathrm{sd}$ & $0 \leq \chi^{2} / \mathrm{sd} \leq 2$ & $2 \leq \chi^{2} / \mathrm{sd} \leq 3$ & 2.87 & Acceptable \\
\hline GFI & $.95 \leq \mathrm{GFI} \leq 1.00$ & $.90 \leq \mathrm{GFI} \leq 95$ & 0.90 & Acceptable \\
\hline AGFI & $.90 \leq \mathrm{AGFI} \leq 1.00$ & $.85 \leq \mathrm{AGFI} \leq .90$ & 0.84 & Acceptable \\
\hline CFI & $.95 \leq \mathrm{CFI} \leq 1.00$ & $.90 \leq \mathrm{CFI} \leq .95$ & 0.92 & Acceptable \\
\hline NFI & $.95 \leq \mathrm{NFI} \leq 1.00$ & $.90 \leq \mathrm{NFI} \leq .95$ & 0.88 & Acceptable \\
\hline NNFI & $.95 \leq \mathrm{NNFI} \leq 1.00$ & $.90 \leq \mathrm{NNFI} \leq .95$ & 0.90 & Acceptable \\
\hline IFI & $.95 \leq \mathrm{IFI} \leq 1.00$ & $.90 \leq \mathrm{IFI} \leq .95$ & 0.92 & Acceptable \\
\hline RMSEA & $.00 \leq \mathrm{RMSEA} \leq .05$ & $.05 \leq \mathrm{RMSEA} \leq .08$ & 0.073 & Acceptable \\
\hline SRMR & $.00 \leq \mathrm{SRMR} \leq .05$ & $.05 \leq \mathrm{SRMR} \leq .10$ & 0.050 & Perfect \\
\hline PNFI & $.95 \leq \mathrm{PNFI} \leq 1.00$ & $.50 \leq \mathrm{PNFI} \leq .95$ & 0.75 & Acceptable \\
\hline PGFI & $.95 \leq \mathrm{PGFI} \leq 1.00$ & $.50 \leq \mathrm{PGFI} \leq .95$ & 0.68 & Acceptable \\
\hline
\end{tabular}

$\chi^{2} \mathrm{nd}=569.89, d f=198,90 \%$ Probability Confidence Interval for RMSEA $=(0.066 ; 0.080)$

It was demonstrated with these values that the level of fit of the model obtained from the CFA is sufficient. The $t$ values provided by the CFA are given in Table 4. It was determined that the $t$-values for the items were between 7.93 and 22.73. The $t$ values greater than 1.96 and 2.58 are meaningful at the .05 and .01 levels, respectively (Kline, 2011).

Table 4. $t$ values obtained from CFA.

\begin{tabular}{ll}
\hline Item no & $t$ value \\
\hline I1 & 8.03 \\
I2 & 11.77 \\
I3 & 11.64 \\
I4 & 10.72 \\
I5 & 7.93 \\
I6 & 15.24 \\
I7 & 17.14 \\
I8 & 15.08 \\
I9 & 12.81 \\
I10 & 16.57 \\
I11 & 14.91 \\
I12 & 11.79 \\
I13 & 15.27 \\
I14 & 18.20 \\
I15 & 16.20 \\
I16 & 13.78 \\
I17 & 11.33 \\
I18 & 12.27 \\
I19 & 14.23 \\
I20 & 8.27 \\
I21 & 8.24 \\
I22 & 22.73 \\
\hline
\end{tabular}


Therefore, it was determined that all of the $t$ values are meaningful, and all items should be included in the scale. The factor loads for the one-dimensional model obtained are given in Figure 2. As seen in Figure 2, factor loadings vary between 0.41 and 0.94 .

Figure 2. Measurement model for the scale.

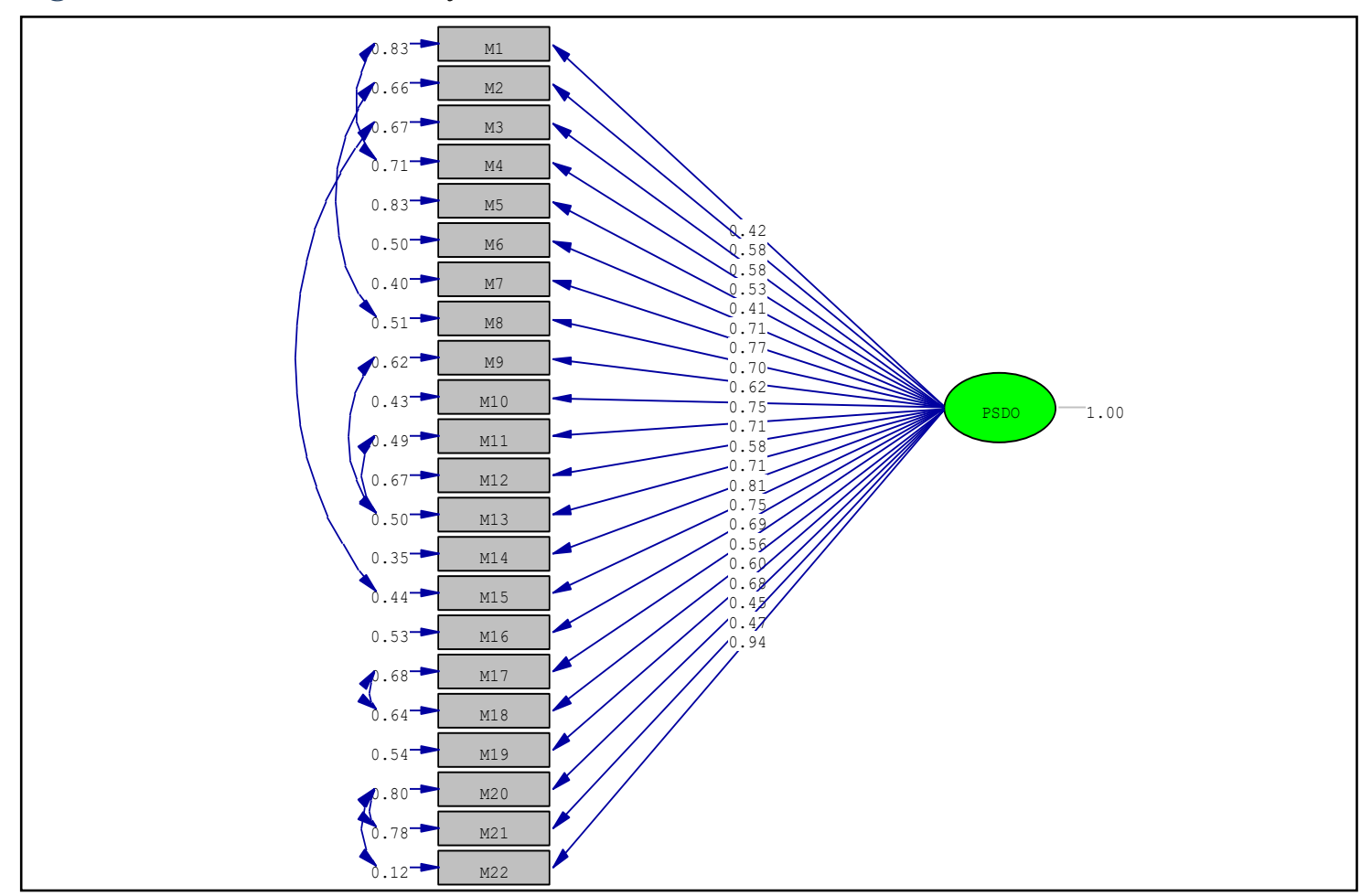

\subsection{The Criterion Validity}

For the criterion-based validity, the HPS and Buss\& Perry Aggression scale was applied to 75 participants. Spearman's rho correlation analysis was performed to determine the relationship between the results obtained from the two scales and a significant relationship was found ( $\mathrm{r}=0.41, p=0.00, p<0.01)$. This result shows that there is a positive relationship between the results obtained from the two scales. This result evidences that the scale can provide valid results.

\subsection{Reliability}

The reliability of the scale was examined based on Cronbach Alpha and test-retest methods. Considering that the measurement results with a reliability coefficient of 0.70 and above are reliable (Crocker \& Algina, 1986), it has been revealed that the calculated 0.93 Cronbach Alpha reliability coefficient is quite high.

The test-retest method was used as the second proof of the reliability of the scale results. The scale, consisting of 22 items, was applied twice with an interval of two weeks and the consistency between the two applications was examined. There was a high level and significant relationship between the two applications with $\mathrm{r}=0.89(p=0.00, p<0.01)$. This result shows that there is agreement between the results obtained from the two applications and there is evidence that the second reliability condition is met.

\subsection{Item Statistics}

In order to determine the discrimination levels of the items and to determine the predictive power of the total score, corrected item-total correlations were calculated and 27\% sub-upper group comparisons were included. The findings obtained as a result of item analysis are shown in Table 5. 
Table 5. Results of item analysis.

\begin{tabular}{cccccc}
\hline Item no & Average & $\begin{array}{c}\text { Standard } \\
\text { deviation }\end{array}$ & $\begin{array}{c}\text { Corrected item-total } \\
\text { correlation }\end{array}$ & $\begin{array}{c}\text { When the item is } \\
\text { removed scale Alpha }\end{array}$ & $t$ \\
\hline I1 & 2.25 & 1.25 & .698 & .927 & 16.32 \\
I2 & 2.14 & 1.24 & .698 & .927 & 17.10 \\
I3 & 1.77 & 1.03 & .693 & .928 & 13.94 \\
I4 & 1.85 & 1.03 & .691 & .928 & 13.40 \\
I5 & 2.49 & 1.34 & .693 & .927 & 17.38 \\
I6 & 2.69 & 1.37 & .680 & .928 & 19.96 \\
I7 & 2.64 & 1.36 & .661 & .928 & 15.81 \\
I8 & 2.29 & 1.31 & .662 & .928 & 14.69 \\
I9 & 2.65 & 1.28 & .656 & .928 & 15.34 \\
I10 & 1.75 & 1.10 & .635 & .929 & 12.40 \\
I11 & 2.14 & 1.17 & .624 & .929 & 14.36 \\
I12 & 3.09 & 1.27 & .630 & .929 & 14.92 \\
I13 & 2.91 & 1.38 & .586 & .929 & 15.87 \\
I14 & 1.85 & 1.11 & .560 & .930 & 11.16 \\
I15 & 1.83 & 1.11 & .554 & .930 & 11.55 \\
I16 & 2.08 & 1.25 & .538 & .930 & 13.97 \\
I17 & 3.01 & 1.34 & .551 & .930 & 10.73 \\
I18 & 2.18 & 1.29 & .531 & .930 & 11.46 \\
I19 & 3.36 & 1.26 & .514 & .931 & 10.34 \\
I20 & 1.66 & 1.01 & .511 & .930 & 10.40 \\
I21 & 2.05 & 1.39 & .460 & .932 & 7.23 \\
I22 & 1.65 & 1.06 & .380 & .932 & 10.54 \\
\hline
\end{tabular}

When the table is examined, it was determined that the $\mathrm{t}$ values $(d f=198, p<0.01)$ regarding the differences in item scores of the $27 \%$ lower and upper groups were significant. Item-total score correlations vary between 0.38 and 0.70 . Items with item-total score correlations over 0.30 are considered discriminating. All of these findings reveal that the items are discriminatory.

\subsection{Evaluation of Scores Obtained from the Scale}

There are 22 items in the scale and there is no reverse item. The scale is a five-point Likert-type as; "Strongly Agree (5), Agree (4), Undecided (3), Disagree (2), and Strongly Disagree (1)". The scale has a one-dimensional structure. The total score is obtained from the scale, and the higher the scores mean the higher the hostility perceptions of the individuals during the pandemic.

\section{DISCUSSION and CONCLUSION}

Covid 19 outbreak threatens mental health as well as physical health. Mental health deterioration and the stress experienced increase the feelings of hostility in the individual. According to Siegman \& Smith (1994), hostility is defined as a negative attitude towards others and especially the feeling of anger. With the Covid-19 outbreak, it is observed that there is social insecurity among people, and this increases hostility (Kim, 2020). This hostility may also be against foreigners or some ethnic groups (Bartos et al., 2020). In the statement published by the World Health Organization (2020) on January 30, 2020 regarding this negative change in the social sense, it was emphasized that countries should be careful against stigmatization and discrimination in the fight against Covid-19. In addition to its social impact, it is seen that hostility in interpersonal relationships increases during the pandemic (Pietromonaco \& Overall2020). Research conducted with 3233 participants in China reveals that individuals with higher stress levels and using negative coping strategies and show more hostility (Duan et al., 
2020). Thus, in this study, it was aimed to develop a measurement tool for determining the hostility levels of individuals during the pandemic.

EFA and CFA were applied to test the construct validity of the scale results. According to EFA results, the factor loads of the items in the scale should be at least 0.32 (Kline 2011, Tabachnick \& Fidell 2007). As a result of EFA, items with insufficient factor loading were removed from the scale and a 22-item scale was created. Tabachnick \& Fidell (2001) and Şencan (2005) stated that the common variance is at least 0.20 . It has been revealed that all items in the scale contribute more than 0.20 to the common variance.

As a result of EFA, a single factor structure that explains $41.5 \%$ of the total variance with 22 items emerged. Çokluk et al., (2012) stated that the variance explained 30\% in one-dimensional structures in social sciences is sufficient. Therefore, it has been revealed that the variance explained by the developed scale is also quite sufficient.

The findings obtained from CFA applied to test whether the structure consisting of 22 items and a single factor obtained as a result of EFA was verified or not, showed that the fit indices of the model were sufficient. In addition, it was revealed that all $t$ values obtained as a result of CFA are meaningful. Byrne (2010) and Şimşek (2007) stated that all t-values in a measurement model are meaningful, the items in the model are compatible with the model and should be included in the scale. Therefore, CFA revealed that all items are necessary for the scale.

Buss\& Perry Aggression Scale were used for Criterion Validity. A significant relationship was found in the Spearman's rho correlation analysis conducted to determine the relationship between the results obtained from the two scales. This result shows that there is a positive relationship between the results obtained from the two scales and there is evidence that the criterion validity is provided.

Cronbach Alpha and test-retest method were used to test the reliability of HPS. Cronbach Alpha reliability coefficient was found as 0.93 and test-retest reliability was found 0.89 as the second proof of the reliability of the scale results. Crocker \& Algina (1986) and Tan (2009) stated that the reliability coefficients in the range of $0.70-0.80$ are acceptable. The results obtained prove that the reliability of the scale results is high.

In order to determine the distinctiveness levels of the items in HPS, and to determine the predictive power of the total score, corrected item-total correlations were calculated, and $27 \%$ sub-upper group comparisons were included. When interpreting the item-total score correlation, items with a value above 0.30 are considered sufficient to distinguish the feature to be measured. The significance of the $t$ values for the differences between the $27 \%$ sub-upper group is also considered as evidence for the distinctiveness of the items (Erkuş, 2012). As a result of the analysis, it was found that item-total score correlations were ranked between 0.38 and 0.70 , and t-values are significant for all items. These findings reveal that the items are distinctive. As a result of all these analyzes, it was determined that HPS is a valid and reliable measurement tool in revealing hostility.

In a study conducted with 1014 people in Spain, it is revealed that threat perception originating from Covid-19 causes negative emotions such as depression, anxiety, anger, and hostility (Pérez et al., 2020). Similarly, when the items were examined in the study conducted, it was observed that anger and negative attitude towards other people are significant and item loads are high. This draws attention to the importance of taking into account the hostility felt during the pandemic in terms of both society and individual health and reveals the necessity of conducting studies to reduce the feelings of stress and hostility by strengthening social support networks. Hence it is thought, this scale will be very useful in terms of examining the factors affecting the mental well-being of the society and increasing the studies supporting well-being. 
When the literature is examined, it is seen that there are measurement tools such as The CookMedley Inventory, The Buss-Durkee Inventory, The Hostility and Direction of Hostility Questionnaire, The NEO-Personality Inventory-Revised, The Rorschach Inkblot Test. However, no scale was found regarding the hostility experienced during the Covid-19 outbreak and thus this study is important in regard of this. The strength of the study is that there is more than one evidence for the validity and reliability of the scale and at the same time a large study group of 855 individuals has been reached. However, the fact that the majority of the individuals in the study group consisted of women is considered as a limitation of the study.

\section{Acknowledgments}

We would like to thank all of the participants who participated in this study for their support.

\section{Declaration of Conflicting Interests and Ethics}

The authors declare no conflict of interest. This research study complies with research publishing ethics. The scientific and legal responsibility for manuscripts published in IJATE belongs to the author(s). For the study, 56665618-204.01.07 numbered Ethical Board approval was taken from İstanbul Okan University Ethical Board.

\section{Authorship Contribution Statement}

Emine Burcu Tunc: Investigation, Resources, Visualization, Software, Formal Analysis, and Writing - original draft. Simel Parlak: Investigation, Resources, Visualization, Software, Formal Analysis, and Writing -original draft. Muge Uluman: Methodology, Supervision, and Validation. Authors may edit this part based on their case. Derya Eryigit: Methodology, Supervision, and Validation. Authors may edit this part based on their case.

\section{ORCID}

Emine Burcu Tunc (iD https://orcid.org/0000-0002-8225-9299

Simel Parlak (D) https://orcid.org/0000-0002-8651-2693

Muge Uluman (i) https://orcid.org/0000-0003-4155-3114

Derya Eryigit (D) https://orcid.org/0000-0002-3708-7176

\section{REFERENCES}

Bartos, V., Bauer, M., Cahlikova, J., Chytilová, J. (2020). Covid-19 Crisis Fuels Hostility Against Foreigners. CESifo Working Paper No. 8309, Available at SSRN: https://ssrn.com/abstract $=3618833$

Becerra-García. J.A., Giménez Ballesta, G., Sánchez-Gutiérrez, T., Barbeito Resa, S., Calvo Calvo, A. (2020). Psychopathological symptoms during Covid-19 quarantine in spanish general population: a preliminary analysis based on sociodemographic and occupationalcontextual factors. Revista Espanola de Salud Publica, 94:e202006059. https://doi.org/1 $\underline{0.1093 / \text { geronb/gbaa074 }}$

Becker, E. W., \& Lesiak, W. J. (1977). Feelings of hostility and personal control as related to depression. Journal of Clinical Psychology, 33(3), 654-657. https://doi.org/10.1002/109 7-4679

Buss, A. H., \& Durkee, A. (1957). An inventory for assessing different kinds of hostility. Journal of Consulting Psychology, 21(4), 343-349. https://doi.org/10.1037/h0046900

Buss, A. H., \& Perry, M. (1992). The aggression questionnaire. Journal of personality and social psychology, 63(3), 452. https://doi.org/10.1037/0022-3514.63.3.452

Byrne, B. M. (2010). Structural equation modeling with AMOS: Basic concepts, applications and programming. Taylor and Francis Group.

Contrada, R. J. (1994). Personality and anger in cardiovascular disease: Toward a psychological model. In A. Siegman, \& T. Smith (Eds.), Anger, hostility, and the heart (pp. 149-170). Erlbaum. 
Cook, W. W. \& Medley, D. M. (1954) Proposed hosulity and Pharisaic-virtue scales for the MMPI. Journal of Applied Psychology, 38, 414-418.

Crocker, L., and Algina, J. (1986). Introduction to classical and modern test theory. Fort Worth: Holt, Rinehart and Winston Inc.

Çokluk, Ö., Şekercioğlu, G., Büyüköztürk, Ş. (2012). Sosyal bilimler için çok değişkenli istatistik: SPSS ve LISREL uygulamalarl [Multivariate statistics for social sciences: SPSS and LISREL applications]. Pegem Akademi Yayınc1lık.

Demirtaş-Madran, H. A. (2012). Buss-Perry saldırganlık ölçeği’nin Türkçe formunun geçerlik ve güvenirlik çalışması [Reliability and Validity of the Buss-Perry Aggression Questionnaire-Turkish Version]. Türk Psikoloji Dergisi, 24(2), 1-6.

Duan, H., Yan, L., Ding, X., Gan, Y., Kohn, N., \& Wu, J. (2020). Impact of the COVID-19 pandemic on mental health in the general Chinese population: Changes, predictors and psychosocial correlates. Psychiatry Research, 293, 113396. https://doi.org/10.1016/j.psy chres.2020.113396

World Health Organization (2020). Statement on the second meeting of the International Health Regulations (2005) Emergency Committee regarding the outbreak of novel coronavirus (2019-nCoV). https://www.who.int/news/item/30-01-2020-statement-on-the-secondmeeting-of-the-international-health-regulations-(2005)-emergency-committeeregarding-the-outbreak-of-novel-coronavirus-(2019-ncov)

Eckhardt, C., Norlander, B., \& Deffenbacher, J. (2004). The assessment of anger and hostility: A critical review. Aggression and Violent Behavior, 9(1), 17-43. https://doi.org/10.1016/ $\underline{\mathrm{S} 1359-1789(02) 00116-7}$

Erkuş, A. (2012). Psikolojide ölçme ve ölçek geliştirme [Measurement and scale development in psychology]. Pegem Akademi Yayınları.

Faay, M. D., Van Baal, G. C. M., Arango, C., Díaz-Caneja, C. M., Berger, G., Leucht, S., ... \& Petter, J. (2020). Hostility and aggressive behaviour in first episode psychosis: Results from the OPTiMiSE trial. Schizophrenia Research, 223, 271-278. https://doi.org/10.101 6/j.schres.2020.08.021Get

Fraenkel, J R, Wallend, N. E., \& Hyun, H. H. (2012). How to design and evaluate research in education. McGraw Hill.

Gambone, G. C. (1998). Cognitive patterns of self- and other-representation as indicators of hostility [Unpublished doctoral dissertation]. The State University of New Jersey-New Brunswick.

Jakovljevic, M., Bjedov, S., Jaksic, N., \& Jakovljevic, I. (2020). COVID-19 pandemia and public and global mental health from the perspective of global health security. Psychiatria Danubina, 32(1), 6-14. https://doi.org/10.24869/psyd.2020.6

Jones, N. M., Thompson, R. R., Schetter, C. D., \& Silver, R. C. (2017). Distress and rumor exposure on social media during a campus lockdown. Proceedings of the National Academy of Sciences, 114(44), 11663-11668. https://doi.org/10.1073/pnas.1708518114

Keith, F., Krantz, D. S., Chen, R., Harris, K. M., Ware, C. M., Lee, A. K., ... \& Gottlieb, S. S. (2017). Anger, hostility, and hospitalizations in patients with heart failure. Health Psychology, 36(9), 829. https://doi.org/10.1037/hea0000519

Kim, B. (2020). Effects of social grooming on incivility in COVID-19. Cyberpsychology, Behavior, and Social Networking, 23(8), 519-525. https://doi.org/10.1089/cyber.2020.0 $\underline{201}$

Kline, R. B. (2011). Principles and practice of structural equation modeling. The Guilford Press.

Lee, S. M., Kang, W. S., Cho, A. R., Kim, T., \& Park, J. K. (2018). Psychological impact of the 2015 MERS outbreak on hospital workers and quarantined hemodialysis patients. 
Comprehensive Psychiatry, 87, 123-127. https://doi.org/10.1016/j.comppsych.2018.10.0 03

Maan Diong, S., Bishop, G. D., Enkelmann, H. C., Tong, E. M., Why, Y. P., Ang, J. C., \& Khader, M. (2005). Anger, stress, coping, social support and health: Modelling the relationships. Psychology \& Health, 20(4), 467-495. https://doi.org/10.1080/088704404 $\underline{0512331333960}$

Miller, T. Q., Smith, T. W., Turner, C. W., Guijarro, M. L., \& Hallet, A. J. (1996). Meta-analytic review of research on hostility and physical health. Psychological Bulletin, 119(2), 322. https://doi.org/10.1037/0033-2909.119.2.322

Özmete, E., Yildirim, H., \& Duru, S. (2018). Yabanci düşmanliği (zenofobi) ölçeğinin Türk kültürüne uyarlanmasi: Geçerlik ve güvenirlik çalişmasi [Adaptation of the scale of xenophobia to Turkish culture: Validity and reliability study]. Sosyal Politika Çalışmaları Dergisi, 18, 191-209. https://doi.org/10.21560/spcd.v18i39974.451063

Pérez-Fuentes, M. D. C., Molero Jurado, M. D. M., Martos Martínez, Á. \& Gázquez Linares, J. J. (2020). Threat of COVID-19 and emotional state during quarantine: Positive and negative affect as mediators in a cross-sectional study of the Spanish population. Plos one, Public Library of Science 15(6), 1-11. https://doi.org/10.1371/journal.pone.0235305

Pietromonaco, P. R., \& Overall, N. C. (2020). Applying relationship science to evaluate how the COVID-19 pandemic may impact couples' relationships. American Psychologist. Advance online publication. http://dx.doi.org/10.1037/amp0000714

Ranchor, A. V., Sanderman, R., Bauma, J., Buunk, B. P., \& van den Heuvel, W. J. (1997). An exploration of the relation between hostility and disease. Journal of Behavioral Medicine, 20(3), 223-240. https://doi.org/10.1023/A:1025538926879

Rosenman, R. H. (1991) Type A behavior pattern and coronary heart disease: The hostility factor?. Stress Medicine, 7(4), 245-253. https://doi.org/10.1002/smi.2460070407

Siegman, A. W. \& Smith, T. W. (1994). Anger, hostility, and the heart. Lawrence Erlbum Associates, Inc.

Spielberger, C. D., Jacobs, G., Russell, S. \& Crane, R. S. (1983). Assessment of anger: The state-trait anger scale. Advances in Personality Assessment, 2, 161-189.

Suls, J. \& Bunde, J. (2005). Anger, anxiety, and depression as risk factors for cardiovascular disease: the problems and implications of overlapping affective dispositions. Psychological bulletin, 131(2), 260.

Şencan, H. (2005). Sosyal ve davranışsal ölçümlerde güvenirlik ve geçerlilik [Reliability and validity in social and behavioral measures]. Seçkin Yayınc1lık.

Şimşek, Ö. F. (2007). Yapısal Eşitlik Modellemesine Giriş: Temel Illkeler ve LISREL Uygulamalart [Reliability and validity in social and behavioral measures]. Ekinoks Yayıncilık.

Tabachnick, B. G. \& Fidell, L. S. (2007). Using multivariate statistics. Pearson Education, Inc. Tan, Ş. (2009). Misuses of KR-20 and Cronbach's alpha reliability coefficients. Eğitim ve Bilim Dergisi, 34, 152, 101-112.

Tavşanc1l, E. (2009). Tutumların ölçülmesi ve SPSS ile veri analizi [Measuring attitudes and data analysis with SPSS]. Nobel Yayın Dağıtım.

Trauer, J. M., Laurie, K. L., McDonnell, J., Kelso, A., \& Markey, P. G. (2011). Differential effects of pandemic (H1N1) 2009 on remote and indigenous groups, Northern Territory, Australia, 2009. Emerging Infectious Diseases, 17(9), 1615.

Van der Veer, K., Ommundsen, R., Yakushko, O., Higler, L., Woelders, S., \& Hagen, K. A. (2013). Psychometrically and qualitatively validating a cross-national cumulative measure of fear-based xenophobia. Quality \& Quantity, 47(3), 1429-1444. https://doi.or $\mathrm{g} / 10.1007 / \mathrm{s} 11135-011-9599-6$ 